\title{
ELASMOBRANCH DIVERSITY WITH PRELIMINARY DESCRIPTION OF FOUR SPECIES FROM TERRITORIAL WATERS OF BANGLADESH
}

\author{
A.B.M. Zafaria, Shamsunnahar, Sanjay Chakraborty, Md. Muzammel Hossain ${ }^{1}$, \\ Md. Masud Rana and Mohammad Abdul Baki* \\ Department of Zoology, Jagannath University, Dhaka-1100, Bangladesh
}

\begin{abstract}
There is a significant lack of data regarding the biodiversity of elasmobranchs in the territorial waters of Bangladesh, since that sharks and rays are not targeted by commercial fishing industry, but rather encountered as a bycatch. This paper updated the diversity of elasmobranchs in the territorial waters of Bangladesh. The study was carried out to identify two coastal areas of Patharghata, Barguna and Cox's Bazar between October, 2015 and September, 2016. Using fish landing station survey techniques, total 20 species of elasmobranch were encountered, including eight species of sharks and 12 species of batoids, under 14 genera, ten families. This is the most expended field based records of elasmobranch fishes of Bangladesh.
\end{abstract}

Key words: Elasmobranch, assessment, diversity, shark, skate, ray

\section{INTRODUCTION}

Elasmobranchs have been evolving independently for at least 450 million years and, by the Carboniferous period, they seem to have developed a lifehistory pattern similar to that seen today. From a practical point of view the lifehistory pattern of elasmobranchs make this group of animals extremely susceptible to over fishing (Harold et al. 1990). The marine fisheries sector of Bangladesh plays a significant role in the county's economic growth through provision of employment in coastal area and providing source of protein for the population but shark fisheries (sharks and rays) are artisanal fisheries in Bangladesh. Bangladesh is located in the northeast corner of the Bay of Bengal (Churchill 2012), it has a markedly concave coastline-indeed; actually its two principal stretches of coast meet almost at right angles. A few species of shark enter in the brackish water and even in the freshwater rivers beyond the tidal ranges, like the Ganges River (Migdalskiet al. 1989). A few works have been completed with the taxonomy of shark species of Bangladesh such as Hussain (1970), Guddus et al. (1988), Rahman et al. (2009), Roy et al. (2014) and Hoq et al. (2014). At least 171 species of elasmobranches, representing 68 genera and 34 families, were recorded from fresh or estuarine waters (Martin 2005).

*Author for correspondence: <mabaki@gmail.com>. ${ }^{1}$ Department of Fisheries and Aquaculture, Sharklab ADRIA, Dhaka, Bangladesh

(C) 2018 Zoological Society of Bangladesh DOI: http://dx.doi.org/10.3329/bjz.v46i2.39052 
Also 27 species of sharks (11 species) and rays (16 species) identified in the Bay of Bengal (Roy et al. 2011). Nine shark species belonging to 3 families (Carcharhinidae, Hemiscylliidae and Sphyrnidae) were recorded (Hasan et al. 2015). The western Indian Ocean and red sea have an extremely diverse shark fauna including 23 families, 62 genera and at least 115 species. Worldwide there are 730 families, 96 genera and about 350 species of sharks (elasmobranchii) (FAO 1983). About 70 species of sharks was found in Indian waters, though only 18 species are occasionally or frequently caught (Hausfather 2004).

The major shark hunting grounds of Bangladesh include the coastal waters of Kuakata, Sonar Char, Ruper Char, Fatrar Char, Char Gongmoti and Dublar Char in Patuakhali and Ashar Char, Patharghata, Barguna, the Sunderbans, Sandwip, Kutubdia, Moheshkhali, Cox's Bazar and Teknaf (Roy et al. 2015). IUCN shark specialist group - 2006 reported that 26\% of Northeast Atlantic elasmobranches threatened within the region $(7 \%$ critically endangered, $7 \%$ endangered, $12 \%$ vulnerable) and globally, of the 1038 species of elasmobranches assessed, 18\% are threatened (3\% CR, 4\% EN, and $11 \% \mathrm{VU}$ ), 13\% near threatened, 23\% least concern and 46\% data deficient (Gibson 2006). Illegal, unregulated and unreported trade is contributing to unsustainable fishing of a number of shark species (CITES 2010). Highest shark fishing countries are Indonesia, India, Taiwan, China, Spain and Mexico and in 2007, global landing was $42 \%$ (Camhi et al. 2009). Ray fisheries are important in many areas of the western central Pacific, with substantial landings off Thailand and Singapore (Compagno 1998). Certain publications are recognized about sharks' population dynamics, in particular concerning their biology and stock assessment (Vannuccini 1999). However, a few people know about elasmobranches from the Bay of Bengal due to lack of adequate scientific investigation and advanced technology. Present investigation attempted to provide baseline information on shark, ray and skates species in the Bay of Bengal.

\section{MATERIAL AND METHODS}

The present study was carried out from October, 2015 to September, 2016 at two coastal regions, Patharghata area in Barguna and Cox's Bazar area, Chittagong.

Barguna: Patharghata area, located in between $22^{\circ} 14^{\prime}$ and $22^{\circ} 58$ north latitudes and in between $89^{\circ} 53^{\prime}$ and $90^{\circ} 05^{\prime}$ east longitudes. Harvesting depth is 5 to $30 \mathrm{~m}$. It is bounded by Mathbaria and Bamna upazilas on the north, Bay of Bengal on the south, Barguna Sadar and the Bishkhali river on the east, Sarankhola upazila and the Haringhata river on the west. 
Cox's Bazar area: Cox's Bazar area, located in between $21^{\circ} 24^{\prime}$ and $21^{\circ} 36^{\prime}$ north latitudes and in between 91 ${ }^{\circ} 59^{\prime}$ and $92^{\circ} 08^{\prime}$ east longitudes. Harvesting depth is 10 to $50 \mathrm{~m}$. It is bounded by Chakaria upazila on the north, Bay of Bengal and Ramu upazila on the south, Ramu upazila on the east, Maheshkhali upazila, Maheshkhali channel and Bay of Bengal on the west.

Regular survey was held at two landing stations to investigate species. Species-wise sharks and rays samples were collected from both landing stations. Unidentified species were preserved in $10 \%$ formalin solution, transported to laboratory to find out major morphological characteristics at taxonomic level. All species were identified based on the morphological features according to Munro (1955), Compagno (1981), Quddus et al. (1988), Talwarand Jhingran (1994), FAO. (1994), Bonfil and Mohammad (2003), Michael (2005), Raje et al. (2007), Rahman et al. (2009).

Calculation of length-length relationships: Length-length relationship was calculated by using equation $\mathrm{Y}=\mathrm{a}+\mathrm{bX}$, (Alam et al. 2012), Where $\mathrm{Y}=$ various body lengths, $\mathrm{X}=$ total length, $\mathrm{a}=$ proportionality constant and $\mathrm{b}=$ regression coefficient.

\section{RESULTS AND DISCUSSION}

During study period a total of 20 species (sharks and rays) under 10 families were identified (Table 1). Among them three families (Sphyrnidae, Hemigaleidae, Carcharhinidae) of shark, and seven families (Dasyatidae, Gymnuridae, Mobulidae, Rhinopteridae, Myliobatidae, Rhinobatidae, Narcinidae) of Rays were recorded. Among eight shark species, four species were recorded earlier by Roy (2010), five species were reported by Roy et al. (2014), and five species by Hoq et al. (2014). Among ray species, five species were reported by Roy (2010), three species were earlier Roy et al. (2014) and nine species were by Hoq et al. (2014). Preliminary information of four significant species describes bellow as distribution.

\section{Hooktooth shark, Chaenogaleus macrostoma (Bleeker, 1852)}

Synonym: Hemigaleus balfouri Day, 1878; Hemigaleus macrostoma Bleeker 1852. Common name: Hooktooth shark, Bengali name: China rihangor. (Fig. 1)

Recorded total length is $80 \mathrm{~cm}$ approximately. Upper side color is bronzy grey and lower side white. Two dorsal fin is present and pectoral fin large then $1^{\text {st }}$ dorsal fin. Maximum total length is $100 \mathrm{~cm}$ and small fishes, crustaceans and cephalopods are used as food. The species is Viviparous (with a yolk-sac placenta) (Compagno 1984). 


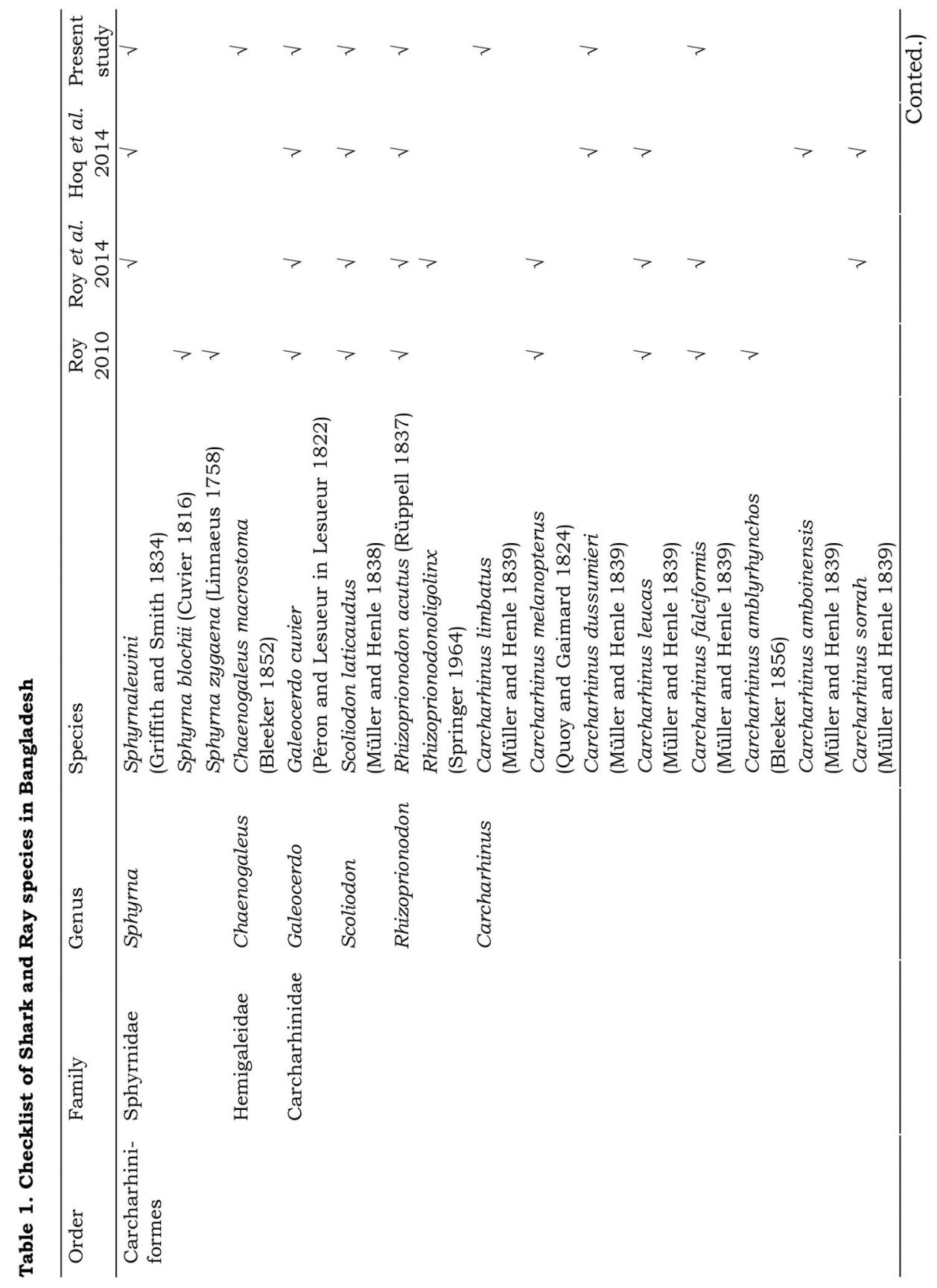




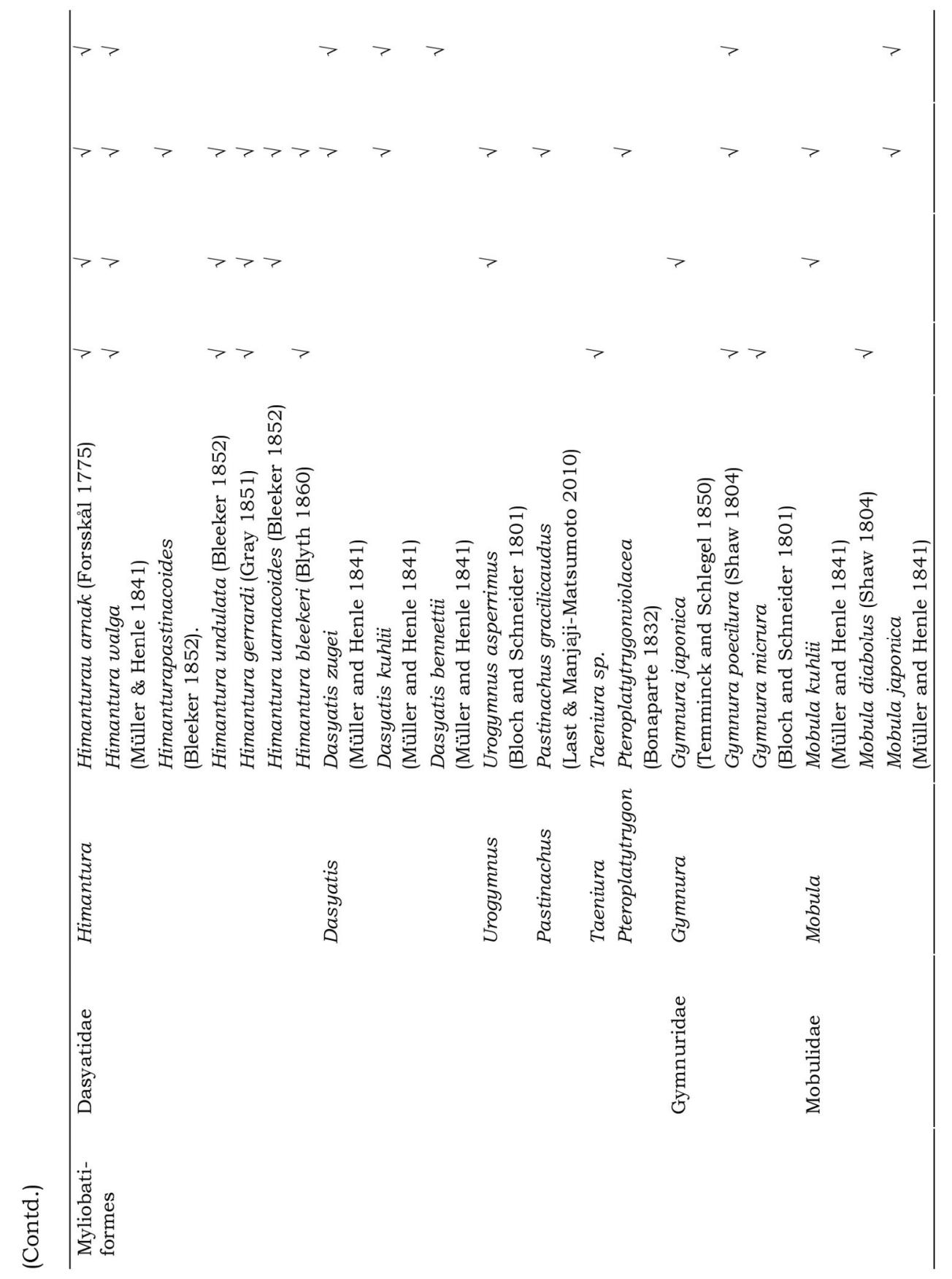




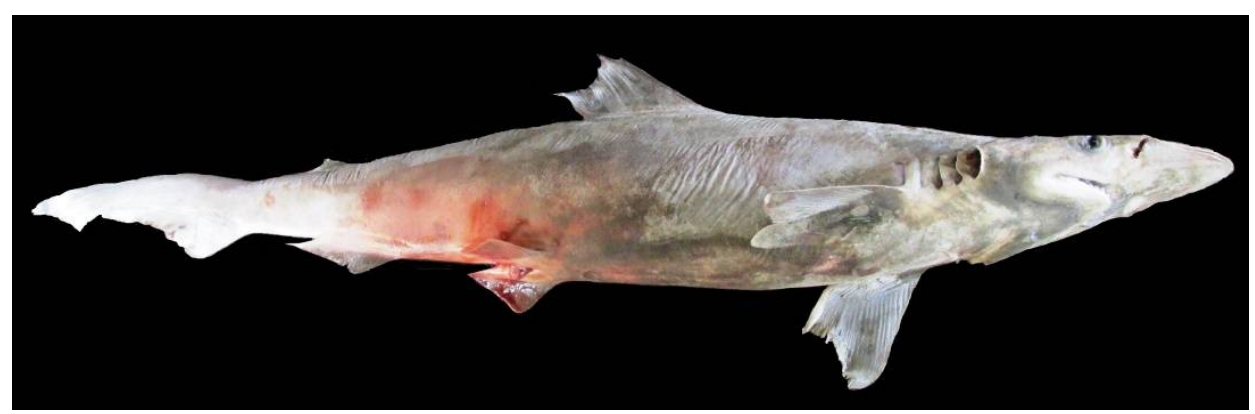

Fig. 1. Chaenogaleus macrostoma (Bleeker, 1852) @ M. M. Hossain

Chaenogaleus macrostoma (Bleeker, 1852) is record form Patharghata, Barguna District $\left(22^{\circ} 14^{\prime}\right.$ and $22^{\circ} 58$ north latitudes, $89^{\circ} 53^{\prime}$ and $90^{\circ} 05^{\prime}$ east longitudes) in Bangladesh as distribution but it's caught irregularly by inshore gillnet fisheries in the Bay of Bengal. Chaenogaleus macrostoma (Bleeker, 1852) was reported from 22 countries/islands and occurrence in Pakistan, India, Sri Lanka, Singapore, Thailand, Vietnam, China, Taiwan, Java and Sulawesi in Indonesia. Indo-West Pacific: Persian Gulf (Compagno 1998).

Special notes: According to IUCN Red list this species is Vulnerable (VU) $(\mathrm{A} 2 \mathrm{bd}+3 \mathrm{bd})$ in the world and also CITES and CMS were not evaluating the species.

\section{Blacktip shark, Carcharhinus limbatus (Müller and Henle, 1839)}

Synonym: Carcharhinus natator Meek and Hildebrand 1923, Carchariasaethlorus Jordan and Gilbert 1882, Carchariasehrenbergi Klunzinger 1871; Carcharias microps Lowe 1841. Common Name: Blacktip shark,Bengali Name: Bolihangor.

(Fig. 2)

Recorded total length is $120 \mathrm{~cm}$ approximately but maximum total length $275 \mathrm{~cm}$ male (Lafrance 1994). Snout is pointed and moderately long. Dorsal side is dark gray or blue to brown and ventral surface is white. The first dorsal fin of the shark is slightly posterior to the pectoral fins. Black color tips are present in the first and second dorsal fins, pectoral fins, pelvic fins, and lower caudal fin lobes. This shark is found in coastal and offshore or adjacent to central and often off river mouths, estuaries, muddy bays, mangrove swamps, lagoons, and coral reef drop-offs (Compagno 1984).

The species is found worldwide in tropical and warm temperate waters (Compagno 1984) but recorded form Patharghata, Barguna District $\left(22^{\circ} 14^{\prime}\right.$ and $22^{\circ} 58$ north latitudes, $89^{\circ} 53^{\prime}$ and $90^{\circ} 05^{\prime}$ east longitudes) in Bangladesh as distribution. Carcharhinus limbatus (Müller and Henle 1839) is one of the most 
abundantly caught species in Bimini, Bahamas (Kessel 2010). This shark is a target species as commercial shark fishery in the United States and the Gulf of Mexico (Branstetter and Burgess 1997).

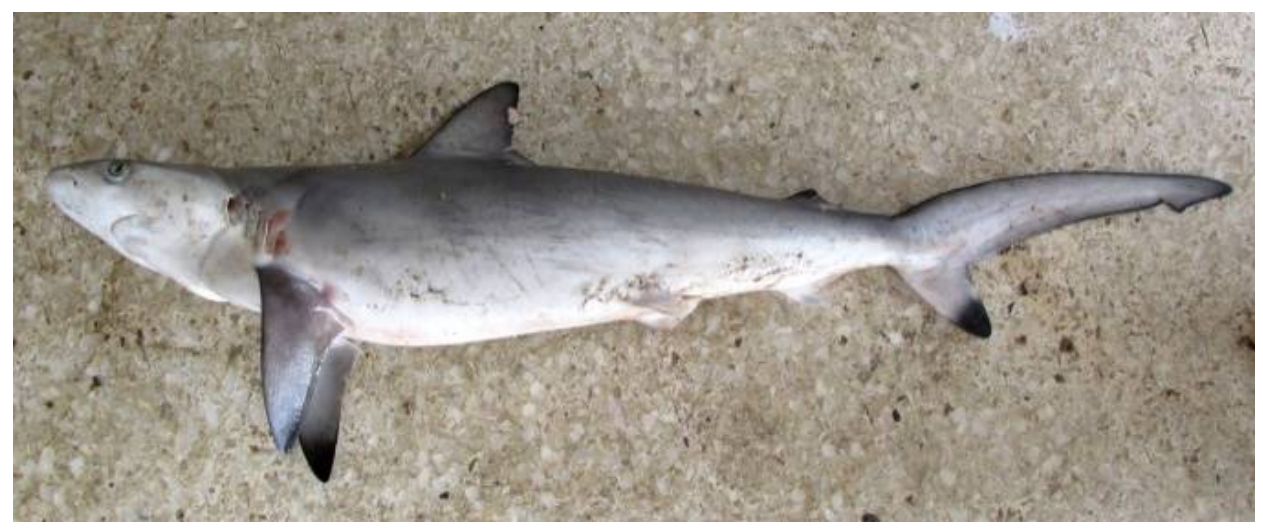

Fig. 2. Carcharhinus limbatus (Müller and Henle 1839). ㅇ M. A. Baki

Special notes: According to IUCN Red list, this species is Near Threatened (NT) in the world but CITES and CMS were not evaluating the species.

\section{Annandale's guitarfish, Rhinobatos annandalei (Norman, 1926)}

Synonym: Not evaluated; Common name: Annandale's guitarfish; Local name: Pitambori.

(Fig. 3)

Recorded total length is $55 \mathrm{~cm}$ approximately. Snout elongate, anteriorly flattened, Stout tail, confluent with trunk. Pectoral fins expanded, attached to the head from nostrils to $1 / 2$ the snout length. Dorsal fins relatively large, pelvic fins single lobed, caudal fin not bilobed, mouth is short and relatively straight, teeth is small molariform, Spiracles well developed. It is ovoviviparous (Dulvy and Reynolds 1997).

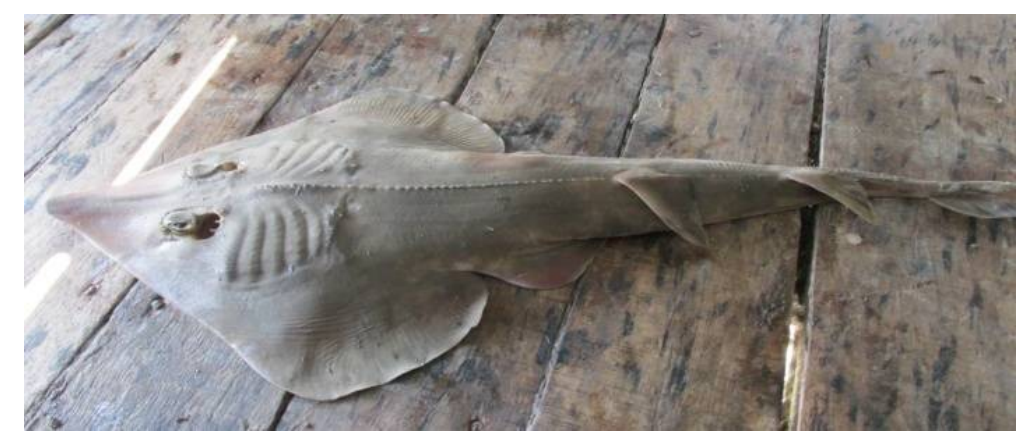

Fig. 3: Rhinobatos annandalei (Norman 1926), (c) M. M. Hossain 
This ray species recorded form Patharghata, Barguna district $\left(22^{\circ} 14^{\prime}\right.$ and $22^{\circ} 58$ north latitudes, $89^{\circ} 53^{\prime}$ and $90^{\circ} 05^{\prime}$ east longitudes)in Bangladesh as distribution. This species enters in the river but mainly occurs in the marine water. Generally it occurs in Indian Ocean: India, Sri Lanka, Pakistan and also possibly from the Gulf (Talwar and Jhingran 1994).

Special notes: According to IUCN red list, insufficient information is available on the species Rhinobatos annandalei (Norman, 1926), distribution, biology and capture in fisheries to assess it beyond Data Deficient (Valenti 2009). CITES and CMS were not evaluating the species.

\section{Bennett's stingray, Dasyatisbennettii (Müller and Henle 1841)}

Synonym: Trygon bennettii Müller and Henle, 1841; Common name: Bennett's stingray; Local name: Shaplapata mach.

(Fig. 4)

Recorded disc width (DW) is $50 \mathrm{~cm}$ and total length $130 \mathrm{~cm}$ approximately but the species reaches a maximum total length (TL) at least $275 \mathrm{~cm}$ male (Lafrance 1994). Snout tip of Hemitrygon bennetti (Müller and Henle 1841) with rhomboid disc triangular and moderately protruding. Species color is yellowish brown upside, becoming darker on the tail fold, and below is lightly. Pectoral fin disk like diamond-shaped, tail is whip-like, stinging spine present on the upper surface of the tail, dermal denticles present in the middle of the back side. Tail length about three times disc length; disc and snout longer; head length about half of disc wide. Small bony fishes and crustaceans used as food (Thollot 1996).

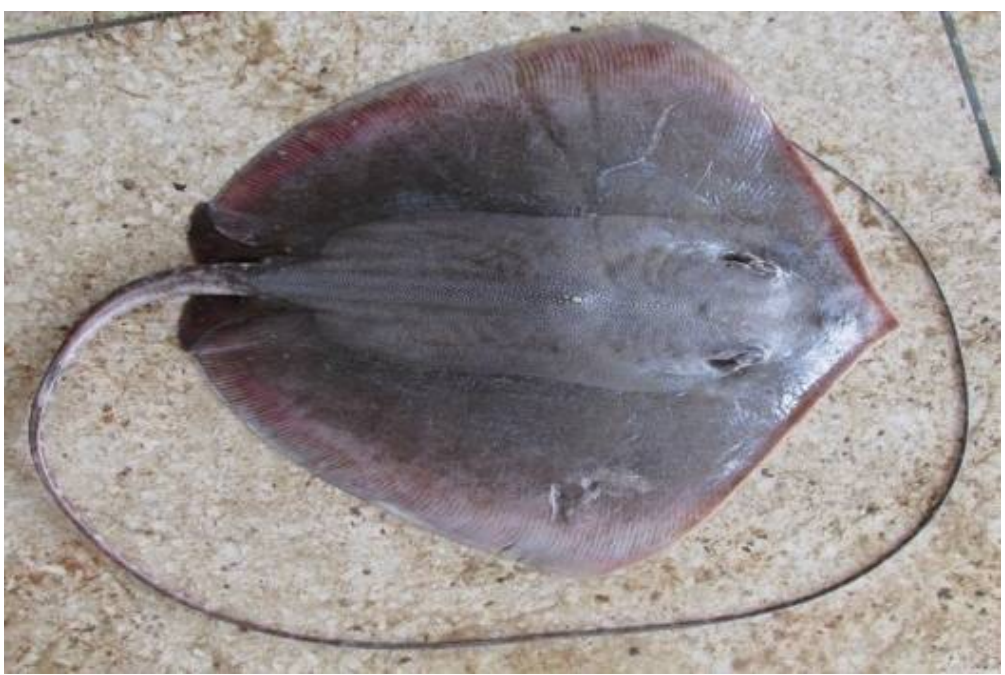

Fig. 4. Dasyatis bennettii (Müller and Henle 1841), (C) M. M. Hossain. 
The species is newly recorded from Cox's Bazar district $\left(21^{\circ} 24^{\prime}\right.$ and $21^{\circ} 36^{\prime}$ north latitudes and in between $91^{\circ} 59^{\prime}$ and $92^{\circ} 08^{\prime}$ east longitudes) in Bangladesh as distribution but found in northwest pacific: Indonesia (Java) to central China, including Taiwan (Compagno 1984).

Special note: According to IUCN red list, insufficient information is available on the species Dasyatis bennettii (Müller and Henle 1841), distribution, biology and capture in fisheries to assess it beyond Data Deficient (Valenti 2016). CITES and CMS are not evaluating the species. Ray fisheries are very important in many areas but no specific information on catches and abundance of population, comparative anatomical study is available.

\section{Length-length relationship (LLR) of S. laticaudus and $R$. acutus:}

About 12500 individuals were observed from the area during this study. The number of individuals varied from 274 in case of species Scoliodon laticaudus to 256 for Rhizoprionodon acutus measuring length from the BFDC, Patharghata during October to November. In S. laticaudus the highest total length (TL) and standard length (SL) were recorded 56.6 and $54.6 \mathrm{~cm}$ in October and the lowest TL and SL were recorded 26.5 and $24.4 \mathrm{~cm}$ in November. The highest mean value of TL was $40.61 \pm 5.461 \mathrm{~cm}$ in November the lowest was $40.08 \pm 5.504 \mathrm{~cm}$ in October. The highest mean value of SL was $39.06 \pm 5.381 \mathrm{~cm}$ in November the lowest was $38.68 \pm 5.36 \mathrm{~cm}$ in October. In October the LLR of S. laticaudus was revealed that the value of "a" "b" and the coefficient value were $0.237,0.970$ and 0.960, respectively. In November values were 0.4060 .972 and 0.994 respectively. In $R$. acutus the highest TL and SL were recorded $60.5 \mathrm{~cm}$ and 58.1 $\mathrm{cm}$ in November and the lowest TL and SL were recorded 27.5 and $26.6 \mathrm{~cm}$ in November. The highest mean value of TL was $43.75 \pm 6.79 \mathrm{~cm}$ in November the lowest was $43.72 \pm 8.18 \mathrm{~cm}$ in October. The highest mean value of SL was 42.22 $\pm 6.564 \mathrm{~cm}$ in November the lowest was $42.00 \pm 7.866 \mathrm{~cm}$ in October. In October the LLR of $R$. acutus was revealed that the value of "a" "b" and the coefficient value was $0.795,0.942$ and 0.960 , respectively. In November values were 0.052 , 0.963 and 0.994 , respectively. The value of LLR $\left(r^{2}>0.9\right)$ indicated that they are highly significant and highly correlated.

\section{CONCLUSION}

This study provides a set of identification characteristics of newly reported shark and ray species morphologically where in eight species of sharks and 12 species of rays were identified. No previous data of the length-length relationships of the Scoliodon laticaudus and Rhizoprinodon acutus was available from Bangladesh and this data updated the fish base information. This basic 
data will help in establishing a sustainable management plan for sharks and rays of Bangladesh.

\section{LITERATURE CITED}

BONFIL, R. and MOHAMED, A. 2003. Field Identification Guide to the Sharks and Rays of Red Sea and Gulf of Aden. Food and Agricultural Organization of United Nation. Rome. p. 1-70.

BRANSTETTER, S. and BURGESS, G.H. 1997. Commercial shark fishery observer program 1996. Tampa: Gulf and South Atlantic Fisheries Development Program; 1997. University of Florida. Florida. USA. p. 1-36.

CAMHI, M.D., VALENTI, S.V., FORDHAM, S.V., FOWLER, S.I. and GIBSON, C. 2009. The Conservation status of Pelagic Sharks and Rays: Report of the IUCN shark Specialist Group Pelagic Shark Red List Workshop. IUCN Species Survival Commission Shark Specialist Group, Newbury. UK. p. 78.

CHURCHILL, R. 2012. The Bangladesh/Myanmar Case: Continuity and Novelty in the Law of Maritime Boundary Delimitation, Camb. J. Intern. and Comp. Law. p. 138.

CITES. 2010. Fifteenth meeting of the Conference of the Parties. Doha (Gatar), 13-25 March, 2010. CoP15 Doc. 53. p. 14.

COMPAGNO, L.J.V. 1981. Legend versus reality: the jaws image and shark diversity. Oceanus 24(4): 5-16.

COMPAGNO, L.J.V. 1984.FAO Species Catalogue. Vol. 4. Sharks of the world. An annotated and illustrated catalogue of shark species known to date. Part 2 - Carcharhiniformes. FAO Fish Synopsis. Rome. FAO 125(4/2): 251-655.

COMPAGNO, L.J.V. 1998. Hemigaleidae. Weasel sharks. p. 1305-1311.

DULVY, N.K. and REYNOLDS, J.D. 1997. Evolutionary transitions among egg-laying, live-bearing and maternal inputs in sharks and rays. Ser. B: Biol. Sci. 264: 1309-1315.

FAO. 1983 Yearbook of fishery statistics. Statistical Yearbook of Fisheries. Anuarioestadístico of pesca. Catches and landings. Catches and quantities landed. Capturasy desembarques, 1981.(in French with English).FAO, Italy, Rome, 52: 356 p.

FAO. 1994. Species Identification Sheets, fishing Area-51, FAO, Italy, Rome, p.1-15.

GIBSON, C., VALENTI, S.V., FOWLER, S.L. and FORDHAM, S.V. 2006. The Conservation Status of Northeast Atlantic Chondrichthyans. Report of the IUCN Shark Specialist Group. Northeast Atlantic Regional red List Workshop. Peterborough. UK.

HAROLD L.P.J., SAMUEL, H.G. and TORU, T. 1990. Elasmobranchs as Living Resources: Advances in the Biology, Ecology, Systematics, and the Status of the Fisheries. U.S. Department of Commerce, NOAA Technical Reports NMFS 90: 1- 528pp.

HASAN, M. M., SARKER, B.S., RAHMAN, M., PATWARY, M.S.A. and SARKER, M. J. 2015. Present Yield Status, Percentage Composition and Seasonal Abundance of Shark in Two Geographically Important Zones of Bangladesh. Fish Aquac. J. 6: 144.

HAUSFATHER, Z. 2004. India's Shark Trade: An Analysis of Indian shark landing based on shark fin exports, Grinnell collage. Lowa.

HOQ, M.E., HAROON M.K.Y. and KARIM, E. 2014. Shark fisheries status and management approach in the Bay of Bengal, Bangladesh. Advances in Fisheries Research in Bangladesh: I. p. 233-246.

HUSSAIN, M.M. 1970. The marine and estuarine fishes of North East part of the Bay of Bengal. Scientific Researches, East Regional Laboratories, Dhaka. 7: 1.

KESSEL, S.T. 2010. Investigation into the behaviour and population dynamics of the lemon shark, Negaprionbrevirostris. Ph.D Thesis, Cardiff University. Cardiff, Wales, UK. 
LAFRANCE, S. 1994. Archipelago of Bijagos: ichthyofauna and elements of marine ecology. (in French with English) Doc. Scient. CIPA No. 1. 66.

MARTIN, R.A. 2005. Conservation of freshwater and euryhaline elasmobranchs: A review. J. Mar. Biol. Ass., UK. 85: 1049-1073.

MICHAEL, S.W. 2005. Reef Sharks and Rays of the World: A Guide to Their Identification, Behaviour and Ecology. ProStar Publications, Maryland. USA.

MIGDALSKI, E.C., FICHTER, G.S. and WEAVER, N. 1989. The fresh and salt water fishes of the world. Greenwich House, New York, USA, 316 p.

MUNRO, I.S.R. 1955. The Marine and Fresh water fishes of Ceylon. Dept. of External Affairs, Canbera, 349 p. +56 pls.

QUDDUS, M.M.A, SARKAR, M.N. and BANERJEE, A.K. 1988. Studies of the Chondrichthyes Fauna (sharks, skates and rays) of the Bay of Bengal. The J. Noami. 5(2): 19-23.

RAHMAN, A.K.A., KABIR, S.M.H., AHMED, M., AHMED, A.T.A., AHMED, Z.U., BEGUM, Z.N.T., HASSAN, M.A. and KHONDKER, M. (ed.) 2009. Encyclopedia of Flora and Fauna of Bangladesh, Marine Fishes. Asiatic Society of Bangladesh. Dhaka. 24: 1-273.

RAJE, S.G., SIVAKAMI, S., RAJ, G.M., KUMAR, P.P.M., RAJU, A. and JOSHI, K.K. 2007. An Atlas on the elasmobranch fishery resources of India, CMFRI special publication, number, 95.

ROY, B. J, SINGHA, N. K., RAHMAN, M. and ALAM, M. F. 2015. In the Bay of Bengal of Bangladesh Region Shark Fisheries Exploitation, Trade, Conservation and Management. Int. J. Comp. Res. Biol. Sci. 2: 54-65.

ROY, B.J., ALI S.M.H., SINGHA, N.K. and RAHMAN, M.G. 2014. Sharks and Rays Fisheries of the Bay of Bengal at the landing centers of Chittagong and Cox's Bazar, Bangladesh. World J. Biol Med. Sci. 1: 1-14.

ROY, B.J., ALAM, F.M., RHAMAN, G.M., SINGHA, N.K. and AKHTAR, A. 2011. Landing trends, species composition and percentage contribution of sharks and rays in Chittagong and Cox's Bazar, Bangladesh. J. Mar. Sci. and Fish, Chittagong University, Chittagong, Bangladesh 2: 6

TALWAR, P.K. and JHINGRAN, A.G. 1994. Inland fishes of India and adjacent countries. Am. S. Icth. Herp. 3: 828-830.

THOLLOT, P. 1996. The mangrove fish of the southwest lagoon of New Caledonia. (Les poissons de mangrove du lagonsud-ouest de Nouvelle-Calédonie.). ORSTOM Publishing, Paris. France. p. 321.

VALENTI, S.V. 2009. Rhinobatosannandalei. The IUCN Red List of Threatened Species 2009: e.T161478A5432942. http://dx.doi.org/10.2305/IUCN.UK.2009-2.RLTS.T161478A5432942.en

VALENTI, S.V. 2016. Hemitrygonbennetti. The IUCN Red List of Threatened Species 2016: e.T161533A1041 14664.http://dx.doi.org/10.2305/IUCN.UK.2016-3.RLTS.T161533A104114 664.en.

VANNUCCINI, S. 1999. Shark utilization, marketing and trade. FAO Fisheries Technical Paper. No. 389. FAO, Rome, Italy. 470 pp. 